\title{
Prevalencia, severidad de maloclusión y necesidad de tratamiento ortodóncico según el índice estético dental
}

Prevalence, severity and malocclusion

orthodontic treatment need aesthetic dental

as the index
Prevalência, gravidade e má oclusão

tratamento ortodôntico precisa índice

estética dentária
Fecha de Recepción

19 de mayo de 2016
Aceptado para su publicación

20 de agosto de 2016
Alina Noelia Peláez

Autor. Tesis para optar al título de Doctor en Odontología de la Facultad de Odontología de la Universidad Nacional del Nordeste. E-mail: alin_peláez@yahoo.com.ar anpelaez@odn.unne.edu.ar

Silvia Matilde Mazza Director

Laura ltatí Giménez Codirector

\section{Resumen}

La maloclusión se presenta con tasas de prevalencia considerablemente altas. Más del $60 \%$ de la población es afectada por esta anomalía, con diferencias de acuerdo al grupo etario, étnico y método de registro. Según la Organización Mundial de la Salud (OMS), en el mundo ocupa el tercer lugar en problemas de salud bucal, junto con otras dificultades relacionadas con la oclusión y el dolor producido por estas. La mayoría de las alteraciones bucales, $y$ en particular las maloclusiones, no son de riesgo de vida pero, por su prevalencia e incidencia, son consideradas un problema de salud pública. Sin embargo, su importancia se establece no sólo por el número de personas que la presentan, sino además, por los efectos nocivos que pueden generar en la cavidad oral, los cuales varían de una a otra persona según sea su intensidad y gravedad.

Se deben valorar y medir de manera adecuada las anomalías de oclusión, para ello es necesario recurrir al uso de índices oclusales. El más utilizado y recomendado por la OMS es el Índice Estético Dental (DAI), que desde su desarrollo ha demostrado ser confiable y válido, así como sencillo y fácil de aplicar. El DAl evalúa los componentes estéticos y anatómicos, otorga a cada una de las características de maloclusión una puntuación determinada, en función de la contribución relativa que dicha característica tiene a la gravedad del conjunto de la maloclusión, lo que permite además el análisis de cada componente o rasgo oclusal en forma independiente en base a 
REVISTA FACULTAD DE ODONTOLOGÍA

ISSN No 1668-7280 - Vol. IX No 1 - 2016

las características clínicas de cada paciente. Brinda información de los aspectos morfológicos, funcionales y estéticos de la maloclusión categorizada en grados de severidad, determinando así la necesidad de tratamiento ortodóncico.

El conocimiento de la prevalencia de maloclusión en función a su grado de severidad y necesidad real de tratamiento, es un factor esencial a la hora de prever la demanda según tipo de asistencia y planificar la asignación de los recursos disponibles de una forma apropiada, debido a que los servicios de ortodoncia no son fácilmente disponibles y accesibles a la población general, buscando promover la oferta de servicios ortodóncicos para la implementación de programas que contemplen acciones preventivas, interceptivas y de tratamiento, teniendo presente que la maloclusión es un problema importante en la salud bucal, estableciendo prioridades de acceso a los recursos asistenciales en la comunidad.

El propósito de este estudio fue determinar la prevalencia, severidad de maloclusión y necesidad de tratamiento ortodóncico de acuerdo al Índice Estético Dental (DAl) y validar la sonda milimetrada William-Fox (Hu-Friedy), como instrumento de medida utilizado por el índice.

Se realizó un estudio observacional, descriptivo de corte transversal, mediante una muestra conformada por 154 pacientes que concurrieron para su atención integral al Hospital Universitario Odontológico de la Facultad de Odontología de la Universidad Nacional de Nordeste (UNNE), seleccionados mediante un Muestreo al Azar Sistemático, en intervalos de I en 10, quedando establecida una muestra del $10 \%$ de la población en estudio. Los pacientes fueron categorizados en dos grupos etarios que cubren el intervalo de edad, de 18 a 35 años denominados adultos jóvenes y de 36 a 65 años denominados adultos maduros. La recolección de datos se realizó a través de un examen clínico, mediante el análisis del DAI, todos los registros clínicos fueron efectuados por un único examinador, entrenado a tal efecto. Para la validación del instrumento de medida se seleccionaron al azar 50 pacientes aplicando el DAl con sonda milimetrada William-Fox (Hu-Friedy) siendo el instrumento utilizado por el índice y con compás de punta seca empleado como instrumento gold standard.
Se observó que el $70 \%$ de los pacientes estudiados presentó necesidad de tratamiento ortodóncico en diferentes grados de severidad de maloclusión, en el $43 \%$ de los casos el tratamiento es obligatorio. Esta alta prevalencia de maloclusión, se mostró reflejada por las anomalías que se presentaron con mayor frecuencia, como ausencia de piezas dentarias visibles (47\%), apiñamiento dentario en una o ambas arcadas (44\%) y la relación molar con deslizamiento anteroposterior de $1 / 2$ cúspide o cúspide completa ( $49 \%$ ).

En el sexo femenino se presentó oclusión normal en el $31 \%$ de los pacientes y en el masculino $28 \%$. La maloclusión muy severa o discapacitante que requiere de tratamiento obligatorio, se presentó en un $35 \%$ de los pacientes de sexo femenino $y$ en un $54 \%$ en el masculino. En el grupo de adultos maduros prevaleció, en un $59 \%$, la maloclusión muy severa, siendo en estos casos el tratamiento obligatorio.

Se observó una alta correlación entre los valores obtenidos con la sonda milimetrada y con el compás de punta seca, se corrobora con un $r=$ 0,999, $\mathrm{p}$ valor $=0,000$.

En conclusión existe una alta prevalencia de maloclusión en diferentes grados de severidad y necesidad de tratamiento ortodóncico en los pacientes del Hospital Universitario Odontológico de la Facultad de Odontología de la UNNE, siendo mayor la necesidad de tratamiento en adultos maduros de sexo masculino.

Las variaciones entre las medidas registradas con la sonda milimetrada y con el compás de punta seca son mínimas y no influyen en la puntuación final del Índice, lo que valida a la sonda milimetrada como instrumento de medida del Índice Estético Dental.

\section{Abstrac}

Malocclusion occurs with high prevalence rates considerably. More than $60 \%$ of the population is affected by this anomaly, with differences according to age group, ethnic and registration method. According to the World Health Organization (WHO), the world ranked third in oral health problems, along with other difficulties related to occlusion and pain caused by these. Most oral alterations, and in particular malocclusions are not life-threatening but its 
prevalence and incidence, are considered a public health problem. However, its importance is established not only by the number of people who have, but also the harmful effects that can be generated in the oral cavity, which vary from person to person depending on their intensity and severity.

Should be assessed and measured properly occlusion anomalies, it is necessary to resort to using occlusal indexes. The most used and recommended by WHO is the Dental Aesthetic Index (DAl), which since its development has proven to be reliable and valid, as well as simple and easy to apply. The DAl evaluates the aesthetic and anatomical components, gives each one of the characteristics of malocclusion a certain score, depending on the relative contribution that this feature has the gravity of the set of malocclusion, which also allows the analysis of each component or occlusal trait independently based on each patient's clinical characteristics. It provides information morphological, functional and aesthetic aspects of malocclusion categorized in degrees of severity, thus determining the need for orthodontic treatment.

Knowledge of the prevalence of malocclusion according to their degree of severity and real need for treatment, is an essential factor when forecasting demand by type of assistance and plan the allocation of resources in an appropriate manner available because that orthodontic services are not readily available and accessible to the general population, seeking to promote the provision of orthodontic services for the implementation of programs that include preventive, interceptive and treatment actions, bearing in mind that malocclusion is a major problem in health buccal, prioritizing access to health care resources in the community.

The purpose of this study was to determine the prevalence, severity of malocclusion and orthodontic treatment need according to Aesthetic Index Dental (DAI) and validate the millimeter probe William-Fox (Hu-Friedy), as a measuring instrument used by the index.

An observational, descriptive cross-sectional study was conducted using a sample consisting of 154 patients attending for comprehensive care Dental University Hospital, Faculty of Dentistry, National University of Nordeste (UNNE), selected through a sampling Systematic Random at intervals of $I$ in I0, leaving established a sample of $10 \%$ of the study population. Patients were categorized into two age groups covering the age range of 18 to 35 years called and young adults 36 to 65 years called mature adults. Data collection was performed through a clinical examination, by analyzing the DAl, all clinical records were made by a single examiner, trained for this purpose. For validation of the measuring instrument they were randomly selected 50 patients using the DAI with millimetric-Fox William probe (Hu-Friedy) being the instrument used by the index and drypoint compass instrument used as gold standard.

It was observed that $70 \%$ of patients studied had need for orthodontic treatment in varying degrees of severity of malocclusion in $43 \%$ of cases treatment is mandatory. This high prevalence of malocclusion, he was reflected by abnormalities that occurred more frequently, as the absence of teeth visible (47\%), dental crowding in one or both arches (44\%) and the molar ratio with anteroposterior sliding $1 / 2$ or full height apex (49\%).

In the female normal occlusion it occurred in $31 \%$ of patients and $28 \%$ male. Very severe or disabling malocclusion requiring compulsory treatment, was presented by $35 \%$ of female patients and $54 \%$ in males. In the group of mature adults it prevailed, by $59 \%$, very severe malocclusion, being in these cases compulsory treatment.

A high correlation between the values obtained with millimetric probe and compass drypoint was observed, it is confirmed with $r=$ $0.999, \mathrm{p}$ value $=0,000$.

In conclusion there is a high prevalence of malocclusion in different degrees of severity and need for orthodontic treatment in patients at University Hospital Dental School of Dentistry UNNE, with a greater need for treatment in mature adult males.

Variations between the measurements recorded with millimetric probe and compass drypoint are minimal and do not influence the final score of the Index, which validates the millimeter probe as a measuring instrument Dental Aesthetic Index. 
REVISTA FACULTAD DE ODONTOLOGÍA

ISSN No 1668-7280 - Vol. IX No 1 - 2016

76
RESUMEN DE TESIS

Peláez

\section{Resumo}

Má oclusão ocorre com altas taxas de prevalência consideravelmente. Mais de $60 \%$ da população é afetada por essa anomalia, com diferenças de acordo com a faixa etária, método étnica e de registro. De acordo com a Organização Mundial da Saúde (OMS), o mundo ficou em terceiro lugar em problemas de saúde bucal, juntamente com outras dificuldades relacionadas à oclusão e dor causada por estas. A maioria das alterações bucais, e em más oclusões particulares não estão com risco de vida, mas a sua prevalência e incidência, são considerados um problema de saúde pública. No entanto, a sua importância é estabelecida não só por o número de pessoas que têm, mas também os efeitos nocivos que podem ser gerados na cavidade oral, que pode variar de pessoa para pessoa, dependendo a sua intensidade e gravidade.

Devem ser avaliados e medidos oclusão adequadamente anomalias, é necessário recorrer ao uso de índices oclusais. O mais utilizado e recomendado pela OMS é o Índice de Estética Dentária (DAl), que desde o seu desenvolvimento provou ser confiável e válido, bem como simples e fácil de aplicar. A DAl avalia os componentes estéticos e anatómicos, dá a cada uma das características de má oclusão uma determinada pontuação, dependendo da contribuição relativa que esta característica tem a gravidade do conjunto de má oclusão, o que também permite a análise de cada componente ou característica oclusal baseado independentemente das características clínicas de cada paciente. Ele fornece morfológica informação, aspectos funcionais e estéticos da má oclusão classificados em graus de severidade, determinando, assim, a necessidade de tratamento ortodôntico.

O conhecimento da prevalência de má oclusão de acordo com o seu grau de gravidade e real necessidade de tratamento, é um fator essencial ao prever a demanda por tipo de assistência e planejar a alocação de recursos de forma adequada disponível porque que os serviços ortodônticos não são prontamente disponíveis e acessíveis à população em geral, procurando promover a prestação de serviços ortodônticos para a implementação de programas que incluem preventivas ações, interceptores e tratamento, tendo em conta que a má oclusão é um problema importante na saúde bucal, priorizando o acesso aos recursos de saúde na comunidade.

O objetivo deste estudo foi determinar a prevalência, severidade da má oclusão e tratamento ortodôntico precisa de acordo com Índice de Estética Dental (DAI) e validar a sonda milímetro William-Fox (Hu-Friedy), como um instrumento de medição usado pelo índice.

Um estudo transversal observacional, descritivo foi realizado com uma amostra composta por I54 pacientes atendidos pelo atendimento integral Hospital Dental University, Faculdade de Odontologia, Universidade Nacional de Nordeste (UNNE), selecionados através de uma amostragem aleatória sistemática em intervalos de I em I0, deixando estabelecida uma amostra de $10 \%$ da população do estudo. Os pacientes foram divididos em dois grupos etários que cobrem a faixa etária de 18 a 35 anos chamados e jovens adultos de 36 a 65 anos chamados adultos maduros.

A coleta de dados foi realizada através de um exame clínico, através da análise da DAI, todos os registros clínicos foram feitos por um único examinador, treinados para este fim. Para a validação do instrumento de medição que foram selecionados aleatoriamente 50 pacientes usando a DAl com milimétrica-Fox William sonda (Hu-Friedy) ser o instrumento utilizado pelo instrumento indicador e drypoint compasso utilizado como padrão-ouro.

Observou-se que $70 \%$ dos pacientes estudados tinham necessidade de tratamento ortodôntico em diferentes graus de severidade da má oclusão em $43 \%$ dos casos, o tratamento é obrigatória. Esta alta prevalência de má oclusão, ele foi refletido por anomalias que ocorreram mais frequentemente, como a ausência de dentes visíveis (47\%), apinhamento dentário em um ou ambos os arcos (44\%) e a razão molar com ântero-posterior deslizante $1 / 2$ ou ápice de altura total (49\%).

$\mathrm{Na}$ fêmea oclusão normal ocorreu em 31\% dos pacientes do sexo masculino e $28 \%$. Muito grave ou incapacitante má oclusão que requer tratamento obrigatório, foi apresentada por $35 \%$ dos pacientes do sexo feminino e $54 \%$ em homens. No grupo de adultos maduros que prevaleceu, em 59\%, má oclusão muito severa, 
sendo nestes casos, o tratamento obrigatório.

Uma alta correlação entre os valores obtidos com a sonda milimétrica e drypoint bússola é observado, confirma-se com $r=0,999$, valor de $\mathrm{p}=0,000$.

Em conclusão, há uma alta prevalência de má oclusão em diferentes graus de gravidade e necessidade de tratamento ortodôntico em pacientes no Hospital Universitário da Faculdade de Odontologia de Odontologia UNNE, com uma maior necessidade de tratamento em homens adultos maduros.

As variações entre as medições gravadas com sonda milimétrica e compasso drypoint são mínimas e não influenciam o resultado final do índice, o que valida a sonda milímetro como um instrumento de medição Dental Índice de Estética.

\section{Bibliografía}

I. Di Santi MJ, Vásquez VB. Maloclusión Clase I: Definición, clasificación, características clínicas y tratamiento. Rev. Latinoam. Ortod. Odontopediatr. [en línea] 2006 [fecha de acceso 12/03/2015]; Disponible en: www.ortodoncia.ws.

2. Canut J. Un análisis estético dentofacial. REO. 20I4; 44 (I): 43-58.

3. Baca-García A, Baca P, Bravo M, Baca A. Valoración y medición de las maloclusiones: Presente y futuro de los índices de maloclusión. Revisión bibliográfica. Arch. Odontoestomatol. 2002; 18 (9): 654-62.

4. Guerrero C, Marín D, Galvis A. Evolución de la Patología Oclusal: Una Revisión de Literatura. J Oral Res. 20।3; 2 (2): 77-85.

5. Knösel M, Jung K. On the relevance of ideal occlusion concepts for incisor inclination target definition. Am J Orthod Dentofacial Orthop. 20I I; I 40 (5): 652-9.

6. Svedström Oristo AL, Pietilä T, Pietilä II, Alanen P, J Varrela. Morphological, functional and aesthetic criteria of acceptable mature occlusion. European Journal of Orthodontics. 200I; 3 (23): 373-8I.

7. Canut Brusola JA. Oclusión normal y maloclusión. Ortodoncia clínica y terapéutica. $2^{\mathrm{a}}$ ed. Barcelona. Masson S.A.; 2005. p. 95-104.

8. Solarte J, Rocha A, Agudelo AA. Perfil epidemiológico de las alteraciones de la oclusión en la población escolar del corregimiento de Genoy, municipio de Pasto, Colombia. Rev Fac. Odontol. Univ. Antioq. 20 I ; 23 (I): I I I-I 25.

9. Aikins EA, da Costa OO, Onyeaso CO, Isiekwe MC. Self-Perception of Malocclusion Among Nigerian Adolescents Using The Aesthetic Component of The IOTN. The Open Dentistry Journal. 20I2, 6 (6I): 66-I.

10. Chauhan D, Sachdev V, Chauhan T, Gupta KK. A study of malocclusion and orthodontic treatment needs according to dental aesthetic index among school children of a hilly state of India. J Int Soc Prev Community Dent. 20I3; 3 (I): 32-7.

II. Farah S. Abdul R, Mohamed AM, Nor MM, Saub R. Malocclusion and orthodontic treatment need evaluated among subjects with Down syndrome using the Dental Aesthetic Index (DAl). The Angle Orthodontist. 2014; 84 (4): 600-06.

12. Jenny J, Cons NC, Kohout FJ, Jakobsen J. Predicting handicapping malocclusion using the Dental Aesthetic Index (DAI). Int Dent J. 1993; 43:128-32. 
13. Jenny J, Cons NC. Comparing and contrasting two orthodontic indices, the Index of Orthodontic Treatment Need and the Dental Aesthetic Index. Am J Orthod Dentofacial Orthop. 1996; I 10: 410-6.

14. Beglin FM, Firestone AR, Beck FM, Kuthy RA, Wade D. A comparison of the reliability and validity of 3 occlusal indexes of orthodontic treatment need. Am J Orthod Dentofacial Orthop. 200I; I 20: 240-6.

15. OMS. Encuestas de salud Bucodental. Métodos Básicos. Organización Mundial de la Salud. $4^{\text {ta }}$ ed. Ginebra; 1997.p. 46-52.

16. Laboren M, Medina C, Viloria C, Quirós O, D' Jurisic A, Alcedo C, y Col. Hábitos Bucales más frecuentes y su relación con maloclusiones en niños con dentición Primaria. Rev. Latinoam. Ortod. Odontopediatr. [en línea]. 2010 [fecha de acceso 18/05/2015]. Disponible en: www.ortodoncia.ws.

17. Kassis A, Bou Serhal J, Bassil Nassif N. Malocclusion in Lebanese orthodontic patients: an epidemiology and analytic study. Anobservational retrospective study. IAJD. 2010; I: 35-43.

18. Álvarez $R$, Bolasco $A$, Buño AG, Lúgaro $A$, Pascuali L, Santos M. Son las maloclusiones un problema de salud pública en el Uruguay. Acta Odontol. 20I0; 7(I):57-68.

19. González Barrón S, Rivera Cisneros AE, Tena Tamayo C, Sánchez González JM, Manuell GR,
Triana Estrada J. y col. Recomendaciones para mejorar la práctica odontológica. Rev. Conamed. 2004; (3): 109-116.

20. Hassan R, Rahimah AK, Review Article. Occlusion, maloclusión and method of measurements and overview. Arch Orofac Sci. 2007; 2 (2): 3-9.

21. Cano C, Rosas C, Gutiérrez N, Velásquez Y, Godoy S, Quirós O y Col. Frecuencia de maloclusión en niños de 5 a 9 años en una zona rural del Estado Guárico período 2007-2008. Rev. Latinoam. Ortodon. Odontopediatr. [en línea] 2008 [fecha de acceso 18/05/2015]. Disponible en: www.ortodoncia.ws.

22. Oliveira CM, Sheiham A. Orthodontic treatment and its impact on oral held related quality of life in Brazilian adolescents. J. Orthod. 2004; 3 I(I):2027.

23. Peres KG, Traebert ESA, Marcenes W. Diferenças entre autopercepção e critérios normativos na identificação das oclusopatias. Rev. Saúde Pública 2002; 36(2): 230-6.

24. Onyesso CO, Sanu OO. Perception of personal dental appereance in Nigerian adolescents. Am J Orthod. Dentofac. Orthop. 2005; 127 (6): 700-6.

25. Polit D, Hungler B. Investigación Científica en Ciencias de la Salud. $6^{\text {ta }}$ ed. México: Mc GrawHill Interamericana; 2007. p 389- 405.

26. Hernández Sampieri R, Fernández C. Collado PB. Metodología de la Investigación. $4^{\text {ta }}$ ed. México: Mc. Graw - Hill Interamericana; 2006.p 287-399. 